\title{
Calcium release from eggshell by nutrient-solubilizing bacteria
}

\author{
Liberação de cálcio da casca do ovo por bactérias solubilizadoras de nutrientes \\ Liberación de calcio de la cáscara de huevo por bacterias solubilizadoras de nutrientes
}

Received: 01/29/2022 | Reviewed: 02/04/2022 | Accept: 02/13/2022 | Published: 02/18/2022

\author{
Nágila Haick Silveira \\ ORCID: https://orcid.org/0000-0002-9461-2184 \\ Universidade José do Rosário Vellano, Brasil \\ E-mail:_Nagilahaick_8@hotmail.com \\ Ana Beatriz Carvalho Terra \\ ORCID: https://orcid.org/0000-0002-1912-0059 \\ Universidade José do Rosário Vellano, Brasil \\ E-mail: anabeatriz.terra@hotmail.com \\ Carla Neves Toledo \\ ORCID: https://orcid.org/0000-0002-1966-7070 \\ Universidade José do Rosário Vellano, Brasil \\ E-mail: carlantoledo@yahoo.com.br \\ Flavia Romam da Costa Souza \\ ORCID: https://orcid.org/0000-0003-0482-822X \\ Universidade José do Rosário Vellano, Brasil \\ E-mail: flavia_romam@hotmail.com \\ Tayla Evellin Oliveira \\ ORCID: https://orcid.org/0000-0001-5184-6549 \\ Universidade José do Rosário Vellano, Brasil \\ E-mail: taylaeoliveira@hotmail.com \\ Dalvana de Sousa Pereira \\ ORCID: https://orcid.org/0000-0002-7996-638X \\ Universidade José do Rosário Vellano, Brasil \\ E-mail: dalvanaagr@gmail.com \\ Elisa Rocha \\ ORCID: https://orcid.org/0000-0003-3210-0287 \\ Universidade José do Rosário Vellano, Brasil \\ E-mail: elisa.rocha@aluno.unifenas.br \\ José Ricardo Mantovani \\ ORCID: https://orcid.org/0000-0002-9817-8143 \\ Universidade José do Rosário Vellano, Brasil \\ E-mail: jose.mantovani@unifenas.br \\ Adauton Vilela Rezende \\ ORCID: https://orcid.org/0000-0001-8515-484X \\ Universidade José do Rosário Vellano, Brasil \\ E-mail: adauton.rezende@unifenas.br \\ Ligiane Aparecida Florentino \\ ORCID: https://orcid.org/0000-0001-9092-3017 \\ Universidade José do Rosário Vellano, Brasil \\ E-mail: ligiane.florentino@unifenas.br
}

\begin{abstract}
Eggshell is a nutrient-rich residue and can be used as a soil amendment and fertilizer. However, it has a slow release, making its use unfeasible, but microorganisms can accelerate the process of nutrient release. Based on this, the objective was to evaluate the solubilization of the eggshell in the culture medium and in the soil by bacterial strains. Two experiments were installed in a completely randomized design, which consisted of 13 treatments, 12 bacterial strains and a control experiment without inoculation. The first experiment was carried out in a $13 \times 2$ factorial scheme with minimal medium containing eggshell or $\mathrm{CaCl}_{2}$ with four replications. The media were incubated at $28{ }^{\circ} \mathrm{C}$ and after three and seven days the growth, the $\mathrm{pH}$ of the medium and the concentration of soluble $\mathrm{Ca}^{2+}$ were evaluated by flame atomic emission spectrometry. The second experiment was carried out in plastic flasks in which $175 \mathrm{~g}$ of soil and 0.75 $\mathrm{g}$ of eggshell were inserted. After incubation, the $\mathrm{pH}$ in $\mathrm{CaCl}_{2}$, the potential acidity $(\mathrm{H}+\mathrm{Al})$ and the concentration of $\mathrm{K}^{+}, \mathrm{Ca}^{2+}$ and $\mathrm{Mg}^{2+}$ were evaluated. In the final analysis, the bacterial strains did not change the $\mathrm{pH}$ and $\mathrm{Ca}^{2+}$ values of the culture medium in the in vitro experiment. In the soil experiment, strains 100-40 and 100-5 showed the ability to solubilize eggshell calcium.
\end{abstract}

Keywords: Alternative source of calcium; Biosolubilization; Environmental sustainability. 


\begin{abstract}
Resumo
A casca de ovo é um resíduo rico em nutrientes e pode ser utilizado como no solo como corretivo e fertilizante. No entanto, apresenta liberação lenta, inviabilizando o uso, mas, os microrganismos podem acelerar o processo de liberação de nutrientes. Baseado nisso, objetivou-se avaliar a solubilização da casca do ovo em meio de cultura e no solo por estirpes bacterianas. Foram instalados dois experimentos em delineamento inteiramente casualizado, que consistiram de 13 tratamentos, sendo 12 estirpes bacterianas e um experimento controle sem inoculação. $\mathrm{O}$ primeiro experimento foi em esquema fatorial 13 x 2 com o meio mínimo contendo casca de ovo ou $\mathrm{CaCl}_{2}$ com quatro repetições. Os meios foram incubados a $28^{\circ} \mathrm{C}$ e após três e sete dias foram avaliados o crescimento, o pH do meio e a concentração de Ca ${ }^{2+}$ solúvel por espectrometria de emissão atômica com chama. O segundo experimento foi realizado em frascos plásticos em que foram inseridos $175 \mathrm{~g}$ de solo e $0,75 \mathrm{~g}$ de casca de ovo. Após a incubação, foram avaliados o $\mathrm{pH}$ em $\mathrm{CaCl}_{2}$, a

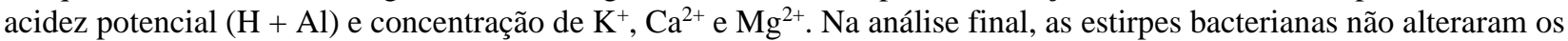
valores de $\mathrm{pH} \mathrm{e} \mathrm{Ca}^{2+}$ do meio de cultura no experimento in vitro. No experimento em solo, as estirpes 100-40 e 100-5 mostraram capacidade de solubilizar o cálcio da casca do ovo.
\end{abstract}

Palavras-chave: Fonte alternativa de cálcio; Biossolubilização; Sustentabilidade ambiental.

\title{
Resumen
}

La cáscara de huevo es un residuo rico en nutrientes y se puede utilizar como enmienda del suelo y fertilizante. Sin embargo, tiene una liberación lenta, haciendo inviable su uso, pero los microorganismos pueden acelerar el proceso de liberación de nutrientes. En base a esto, el objetivo fue evaluar la solubilización de la cáscara de huevo en el medio de cultivo y en el suelo por cepas bacterianas. Se instalaron dos experimentos en un diseño completamente al azar, que constó de 13 tratamientos, 12 cepas bacterianas y un experimento testigo sin inoculación. El primer experimento se llevó a cabo en un esquema factorial 13 × 2 con medio mínimo que contenía cáscara de huevo o $\mathrm{CaCl}_{2}$ con cuatro repeticiones. Los medios se incubaron a $28{ }^{\circ} \mathrm{C}$ y después de tres y siete días se evaluó el crecimiento, el pH del medio y la concentración de $\mathrm{Ca}^{2+}$ soluble por espectrometría de emisión atómica de llama. El segundo experimento se llevó a cabo en frascos de plástico en los que se insertaron $175 \mathrm{~g}$ de suelo y $0,75 \mathrm{~g}$ de cáscara de huevo. Después de la incubación se evaluó el $\mathrm{pH}$ en $\mathrm{CaCl}_{2}$, la acidez potencial $(\mathrm{H}+\mathrm{Al})$ y la concentración de $\mathrm{K}^{+}, \mathrm{Ca}^{2+}$ y $\mathrm{Mg}^{2+}$. En el análisis final, las cepas bacterianas no cambiaron los valores de $\mathrm{pH}$ y $\mathrm{Ca}^{2+}$ del medio de cultivo en el experimento in vitro. En el experimento de suelo, las cepas 100-40 y 100-5 mostraron la capacidad de solubilizar el calcio de la cáscara de huevo.

Palabras clave: Fuente alternativa de calcio; Biosolubilización; Sustentabilidad ambiental.

\section{Introduction}

The sustainable development of agriculture has as one of the main axis the use of agricultural residues in the properties, and the soil microorganisms play a fundamental role in this process since they participate in the decomposition and mineralization of the organic matter present in these compounds (Oliveira et al., 2022). Therefore, the composting of agricultural waste is a sustainable alternative, avoiding soil and water pollution and reducing the use of chemical fertilizers in rural areas (Vital et al., 2018). However, some agricultural residues can be crushed and applied directly to the soil, such as the eggshell (Silveira et al., 2016).

The eggshell contains about $90 \%$ of the calcium in the form of carbonate (Fernandes et al., 2010) and has been tested for the potential for different uses, as human food (Milbradt et al., 2015), extraction of heavy metals (Park et al., 2014) and in agriculture, as a soil pH corrective (King'Ori, 2011). The possibility of using eggshells as an alternative source to soil pH correctors is highly relevant since the limestone rocks are finite (Xiang et al., 2014). Also, the eggshell contains other elements as magnesium, iron, and selenium (Santos et al., 2012), important for plant nutrition. However, Silveira et al. (2016), applied eggshells to replace limestone in the cultivation of Urochloa brizantha cv. Marandu and found no increase in the production of this forage.

The lack of results may be related to the fact that the eggshell is made predominantly of inorganic material (Medeiros \& Alves, 2014), which may present a slow release of chemical elements, a behavior similar to phosphate and silicate rock powders (Ciceri et al., 2015). Thus, further studies are needed to know the behavior and the liberation time of the calcium in the eggshell, for higher safety in recommending it in the soil as a $\mathrm{pH}$ corrective.

In recent years, the concern of Brazilian agriculture with external dependence on fertilizers has increased. Thus, there is a need for research aimed at promoting self-sufficiency in the production of fertilizers. Based on this, one has to several groups 
of soil microorganisms have a proven ability to increase the release of nutrients from phosphate and silicate rocks (Lira-Cadete et al., 2012; Florentino et al., 2017; Pádua \& Florentino, 2022), enabling their use in the soil, increasing production and ensuring the sustainability of agricultural systems.

However, for the calcium present in the eggshell $\left(\mathrm{CaCO}_{3}\right)$, the potential of these microorganisms has not yet been tested. Therefore, the objective of this study was to evaluate the solubilization of eggshell in culture medium and in soil by bacterial strains.

\section{Material and Methods}

Two experiments were carried out at the Soil Microbiology Laboratory of the José do Rosário Vellano University UNIFENAS. Both experiments consisted of 13 treatments (12 bacterial strains and a control without inoculation), with four replications. The bacterial strains selected for this study were isolated from rhizospheric soils of Brachiaria brizantha by Dias et al. (2019) and showed a proven ability to solubilize potassium (Florentino et al., 2017) and phosphorus (Terra et al., 2019).

The first experiment was carried out under axenic conditions (in vitro), using a completely randomized design (CRD) in a factorial scheme with the medium containing eggshell or $\mathrm{CaCl}_{2}$ as calcium source and four replications. The second was performed on the ground in CRD with four replications.

Bacterial strains show rapid growth in culture medium FAM (Magalhães \& Döbereiner, 1984), with the following composition: 5 g sucrose, $0.12 \mathrm{~g} \mathrm{KH}_{2} \mathrm{PO}_{4}, 0.03 \mathrm{~g} \mathrm{~K}_{2} \mathrm{HPO}_{4}, 0.2 \mathrm{~g} \mathrm{MgSO}_{4} 7 \mathrm{H}_{2} \mathrm{O}, 0.02 \mathrm{~g} \mathrm{CaCl}_{2}, 0.066 \mathrm{~g}$ FeEDTA, $0.1 \mathrm{~g} \mathrm{NaCl}$, $0.002 \mathrm{~g} \mathrm{NaMoO}_{4} .2 \mathrm{H}_{2} \mathrm{O}, 0.00235 \mathrm{~g} \mathrm{MnSO}_{4}, 0.0028 \mathrm{~g} \mathrm{H}_{3} \mathrm{BO}_{3}, 8 \times 10^{-5} \mathrm{~g} \mathrm{CuSO}_{4} .5 \mathrm{H}_{2} \mathrm{O}, 0.00024 \mathrm{~g} \mathrm{ZnSO} 4.7 \mathrm{H}_{2} \mathrm{O}, 0.1 \mathrm{mg}$ biotin, 0.2 $\mathrm{mg}$ pyridoxine $\mathrm{HCl}, 1.75 \mathrm{~g}$ agar, $1000 \mathrm{~mL}$ water, adjusted to a $\mathrm{pH}=6.0$. Table 1 shows the characteristics of the bacterial strains, as well as the ability to solubilize phosphorus (Terra et al., 2019) and potassium (Florentino et al., 2017).

Table 1. Identification, medium in which the bacteria were isolated, morphological characteristics and ability to solubilize phosphorus $(\mathrm{P})$ and potassium $(\mathrm{K})$ by the bacterial strains used in the study.

\begin{tabular}{|c|c|c|c|c|c|c|}
\hline \multirow{2}{*}{ Strains } & \multirow{2}{*}{$\begin{array}{c}\text { Isolation } \\
\text { medium }\end{array}$} & \multicolumn{3}{|c|}{ Morphological characteristics in FAM medium } & \multicolumn{2}{|c|}{ Solubilization } \\
\hline & & Medium $\mathrm{pH}$ & Colony color & EPS Production ${ }^{1}$ & Phosporus $^{2}$ & Potassium $^{3}$ \\
\hline $100-13$ & $\mathrm{JNFb}$ & Acid & Yellow & High & + & + \\
\hline $100-16$ & JMV & Acid & Yellow & Low & + & + \\
\hline $100-21$ & $\mathrm{JNFb}$ & Acid & Yellow & Low & + & + \\
\hline $100-39$ & $\mathrm{JNFb}$ & Acid & Yellow & Medium & + & + \\
\hline $100-40$ & $\mathrm{JNFb}$ & Acid/Alkaline & Yellow & Low & + & + \\
\hline $100-55$ & JMV & Ácid & Yellow & High & - & + \\
\hline $100-63$ & LGI & Acid/Alkaline & Yellow & High & + & + \\
\hline $100-68$ & JMV & Ácid & Cream & Low & - & + \\
\hline $100-79$ & LGI & Acid/Alkaline & Yellow & High & - & + \\
\hline $100-93$ & JMV & Acid/Alkaline & Yellow & High & - & + \\
\hline $100-167$ & $\mathrm{NFb}$ & Ácid & Yellow & Low & - & + \\
\hline $100-198$ & LGI & Ácid & Cream & Medium & - & + \\
\hline
\end{tabular}

${ }^{1}$ EPS - production of exopolysaccharides; ${ }^{2}$ Data based on Terra et al. (2019) and ${ }^{3}$ Florentino et al. (2017). Source: Authors (2022).

In the in vitro experiment, the bacterial strains were cultivated in plates containing FAM medium until the emergence of isolated colonies for confirmation of purity. Subsequently, these were cultured into liquid FAM medium and incubated at 28 ${ }^{\circ} \mathrm{C}$ for three days, enough time to reach the logarithmic growth phase, in which the number of colony-forming units (CFU) was approximately $10^{8} \mathrm{CFU} \mathrm{mL} \mathrm{mL}^{-1}$. Then, $300 \mu \mathrm{L}$ of the bacterial isolate suspension was inoculated into flasks with a capacity of 50 
$\mathrm{mL}$ containing $30 \mathrm{~mL}$ of liquid Minimal Media Mineral (MMM) (Abioye et al., 2012), in their original composition, containing $\mathrm{CaCl}_{2}$ as a source of calcium, and MMM modified by replacing $\mathrm{CaCl}_{2}$ with $5 \mathrm{~g}$ of eggshell.

The eggshell powder used in the experiment was obtained in an egg processing, pasteurization, and dehydration industry, located in Nepomuceno-MG. The eggshell was ground and sieved with a $0.25 \mathrm{~mm}$ ( 60 mesh) mesh. This material was analyzed according to Tedesco et al. (1995), using sulfuric digestion and distillation to quantify N; Nitric-perchloric digestion and P quantification by spectrophotometry; $\mathrm{K}$ by flame photometry and the other nutrients ( $\mathrm{Ca}, \mathrm{S}, \mathrm{Mg}, \mathrm{Cu}, \mathrm{B}, \mathrm{Fe}, \mathrm{Mn}$ and $\mathrm{Zn}$ ) by atomic absorption spectrophotometry. The values are shown in Table 2.

Table 2. Chemical composition of the eggshells used in the experiment.

\begin{tabular}{|c|c|c|c|c|c|c|c|c|c|c|c|}
\hline $\mathrm{pH}$ & $\mathrm{N}$ & $\mathrm{P}$ & $\mathrm{K}$ & $\mathrm{Ca}$ & $\mathrm{Mg}$ & $\mathrm{S}$ & B & $\mathrm{Cu}$ & $\mathrm{Fe}$ & $\mathrm{Mn}$ & $\mathrm{Zn}$ \\
\hline \multicolumn{5}{|c|}{$\ldots \ldots \ldots \ldots \ldots \ldots \ldots . . . \mathrm{g} \mathrm{kg}^{-1}$} & \multicolumn{7}{|c|}{....................... $\mathrm{mg} \mathrm{k}^{-1}$. } \\
\hline 8,1 & 5,3 & 0,9 & 3,8 & 368 & 4,1 & 0,8 & 2 & 2 & 30 & 0,9 & 0,8 \\
\hline
\end{tabular}

Source: Authors (2022).

The treatments were incubated at $28{ }^{\circ} \mathrm{C}$ and shaking at $120 \mathrm{rpm}$. Bacterial growth was evaluated on the third and seventh days of incubation, using the serial dilution technique as described by Popovi et al. (2010). On the seventh day, after aliquoting the bacterial growth, the supernatant was separated by centrifugation $\left(10,000 \mathrm{rpm}, 4^{\circ} \mathrm{C}\right.$, and 20 min), for analysis of the final $\mathrm{pH}$ value and the levels of soluble $\mathrm{Ca}^{2+}$ and $\mathrm{Mg}^{2+}$ by atomic absorption spectrometry (Malavolta et al., 1997).

For the second experiment, the soil was collected in the sector of the Agronomy course, on the Unifenas campus, in the superficial layer (0 to $20 \mathrm{~cm}$ ), being classified as a Oxisol with clay texture. Then, it was air-dried, sieved through a $4 \mathrm{~mm}$ mesh, ground, and sampled for initial routine chemical characterization (Silva, 2019), the values are shown in Table 3.

Table 3. Chemical characterization of the soil.

\begin{tabular}{|c|c|c|c|c|c|c|}
\hline $\mathrm{pH}$ & MO & $\mathrm{P}$ & $\mathrm{K}$ & $\mathrm{Ca}^{2+}$ & $\mathrm{Mg}^{2+}$ & $\mathrm{Al}^{3+}$ \\
\hline $\mathrm{CaCl}_{2}$ & $\mathrm{~g} \mathrm{dm}^{-3}$ & \multicolumn{2}{|c|}{-----mg dm ${ }^{-3}$} & \multicolumn{3}{|c|}{-------- $\mathrm{mmol}_{\mathrm{c}} \mathrm{dm}^{-3}$} \\
\hline 4,5 & 41,0 & 1,0 & 1,2 & 2,7 & 6,0 & 9,0 \\
\hline SB & $\mathrm{t}$ & $\mathrm{T}$ & $\mathrm{V}$ & $\mathrm{m}$ & $\mathrm{H}+\mathrm{Al}$ & P-rem \\
\hline \multicolumn{2}{|c|}{----------mmol $\mathrm{dm}_{\mathrm{c}} \mathrm{dm}^{-3}$} & & $----\%$ & & $\mathrm{mmol}_{\mathrm{c}} \mathrm{dm}^{-3}$. & $\mathrm{mg} \mathrm{L}^{-1}$ \\
\hline 14,0 & 24,0 & 90,0 & 26,0 & 39,0 & 40,0 & 15,0 \\
\hline
\end{tabular}

MO - organic matter; H+Al - Potential acidity; $\mathrm{SB}$ - Total exchangeable bases; $\mathrm{t}$ - CTC effective; T - CTC with pH 7,0; V - bases saturation; $\mathrm{m}$ - aluminum saturation; Prem - residual phosphorus. Source: Authors (2022).

Subsequently, portions equivalent to $0.15 \mathrm{dm}^{3}$ of soil $(175 \mathrm{~g})$ were weighed and received the doses of $0.75 \mathrm{~g}$ of eggshell according to the calculation, considering the calcium content in the eggshell and the demand for liming to raise the base saturation (V) to $70 \%$. After mixing the portions of the soil with the eggshell, according to the treatments, these were transferred to plastic bottles with a capacity of $0.2 \mathrm{dm}^{3}$, moistened with distilled water at about $70 \%$ of the retention capacity. Then, $5 \mathrm{~mL}$ of the bacterial strains cultured in liquid FAM were inoculated. The flasks remained incubated for 90 days.

Soil moisture control was carried out every two days, weighing the flasks and adding water, to maintain the soil's initial moisture content. At the end of the incubation period, portions of the soil were removed and dried in the air, then a soil sample was collected from each flask for chemical analysis of the contents of $\mathrm{Ca}^{2+}$ and $\mathrm{Mg}^{2+}$ (Silva, 2019).

The data were subjected to analysis of variance, and the means were compared using the Scott-Knott test, at $5 \%$ probability, by the Sisvar software (Ferreira, 2014). 


\section{Results and Discussion}

Analyzing the growth results, it was verified that all bacterial strains were able to grow in MMM containing eggshell as a source of calcium. However, the growth of the strains was higher when cultivated in MMM containing $\mathrm{CaCl} 2$ as a source of calcium (Table 4).

Table 4. UFC log averages $\mathrm{mL}^{-1}$ of diazotrophic bacteria grown in Minimum Media Minera (MMM), modified with eggshell or $\mathrm{CaCl}_{2}$ as a source of calcium, at three and seven days of growth.

\begin{tabular}{|c|c|c|c|c|}
\hline \multirow{3}{*}{ Strains } & \multicolumn{4}{|c|}{ Log UFC mL ${ }^{-1}$} \\
\hline & \multicolumn{2}{|c|}{3 days } & \multicolumn{2}{|c|}{7 days } \\
\hline & Eggshells & $\mathrm{CaCl}_{2}$ & Eggshells & $\mathrm{CaCl}_{2}$ \\
\hline $100-13$ & $4,98 \mathrm{Ab}$ & 7,59 Aa & $5,13 \mathrm{Ab}$ & $8,15 \mathrm{Aa}$ \\
\hline $100-16$ & 4,93 Ab & 6,66 Aa & $5,52 \mathrm{Ab}$ & 7,59 Aa \\
\hline $100-21$ & $5,02 \mathrm{Ab}$ & 7,03 Aa & $5,78 \mathrm{Ab}$ & 7,23 Aa \\
\hline $100-39$ & $5,16 \mathrm{Ab}$ & 6,89 Aa & $5,95 \mathrm{Ab}$ & $8,02 \mathrm{Aa}$ \\
\hline $100-40$ & $5,36 \mathrm{Ab}$ & 7,23 Aa & $6,06 \mathrm{Ab}$ & 7,46 Aa \\
\hline $100-55$ & 5,66 Ab & 6,99 Aa & $5,96 \mathrm{Ab}$ & 7,87 Aa \\
\hline $100-63$ & $5,73 \mathrm{Ab}$ & 7,07 Aa & $6,09 \mathrm{Ab}$ & 7,93 Aa \\
\hline $100-68$ & 4,72 Ab & 6,86 Aa & $5,14 \mathrm{Ab}$ & 7,01 Aa \\
\hline $100-79$ & $5,46 \mathrm{Ab}$ & 6,79 Aa & $5,89 \mathrm{Ab}$ & $8,13 \mathrm{Aa}$ \\
\hline $100-93$ & $5,01 \mathrm{Ab}$ & 7,12 Aa & $5,22 \mathrm{Ab}$ & 7,77 Aa \\
\hline $100-167$ & $4,78 \mathrm{Ab}$ & 6,90 Aa & 4,99 Ab & 7,86 Aa \\
\hline $100-198$ & $4,59 \mathrm{Ab}$ & 7,10 Aa & $5,14 \mathrm{Ab}$ & $8,06 \mathrm{Aa}$ \\
\hline
\end{tabular}

Means followed by the different letters, uppercase in the column and lowercase in the row, differ by Scott Knott's test at $5 \%$ probability. Source: Authors (2022).

The lower growth observed in the medium containing eggshell powder is explained by the low solubility of $\mathrm{CaCO}_{3}$, the main constituent of eggshells (Rodrigues \& Ávila, 2017). The $\mathrm{Ca}^{2+}$ and $\mathrm{pH}$ values obtained in the in vitro experiment are shown in Table 5, and it is possible to verify that there was no variation in the $\mathrm{pH}$ of the culture medium for the different treatments.

Table 5. Values of final $\mathrm{pH}$ and calcium $\left(\mathrm{Ca}^{2+}\right)$ soluble $\left(\mathrm{mg} \mathrm{L}^{-1}\right)$ in Minimum Media Mineral (MMM) modified with eggshell, incubated for seven days.

\begin{tabular}{lcc}
\hline Treatament & Final pH & $\mathrm{Ca}^{2+}\left(\mathrm{mg} \mathrm{L}^{-1}\right)$ \\
\hline Controle & $7,62 \mathrm{a}$ & $2,57 \mathrm{a}$ \\
$100-21$ & $7,84 \mathrm{a}$ & $2,35 \mathrm{a}$ \\
$100-16$ & $7,67 \mathrm{a}$ & $2,45 \mathrm{a}$ \\
$100-198$ & $8,07 \mathrm{a}$ & $2,45 \mathrm{a}$ \\
$100-63$ & $7,91 \mathrm{a}$ & $2,51 \mathrm{a}$ \\
$100-40$ & $7,15 \mathrm{a}$ & $2,62 \mathrm{a}$ \\
$100-93$ & $7,61 \mathrm{a}$ & $2,71 \mathrm{a}$ \\
$100-39$ & $7,74 \mathrm{a}$ & $2,98 \mathrm{a}$ \\
$100-167$ & $7,34 \mathrm{a}$ & $1,79 \mathrm{~b}$ \\
$100-68$ & $8,15 \mathrm{a}$ & $2,01 \mathrm{~b}$ \\
$100-55$ & $7,46 \mathrm{a}$ & $2,09 \mathrm{~b}$ \\
$100-79$ & $7,23 \mathrm{a}$ & $2,11 \mathrm{~b}$ \\
$100-13$ & $6,94 \mathrm{a}$ & $2,12 \mathrm{~b}$ \\
\hline Means & 7,57 & 2,37 \\
\hline
\end{tabular}

Means followed by the different letters differ by Scott Knott's test at 5\% probability. Source: Authors (2022). 
Regarding $\mathrm{Ca}^{2+}$ values, it was observed that inoculation with eight bacterial strains (100-21, 100-16, 100-198, 100-63, 100-40, 100-93, 100-39, and BR 322) did not promote an increase in the contents of calcium in the culture medium, being the values of this element similar to the control treatment (Table 5). The treatments inoculated with the strains 100-167, 100-68, 100-55, 100-79, and 100-13 reduced $\mathrm{Ca}^{2+}$ in the culture medium.

Calcium is required in large quantities by bacterial cells, engaging not only an important metabolic process but also structural, as in the plasma membrane (Madigan et al., 2016), suggesting that some of them may be more demanding on $\mathrm{Ca}^{2+}$ for their growth, thus reducing the content of calcium in the culture medium.

According to Thapon and Bougeois (1994), the eggshell contains approximately 94\% calcium carbonate, $1 \%$ calcium phosphate, $1 \%$ magnesium carbonate, and $4 \%$ organic substances. Naemchanthara et al. (2008), found that the $\mathrm{CaCO}_{3}$ from eggshell decomposes at a higher temperature than the industrial $\mathrm{CaCO}_{3}$, which may indicate a longer release time from the eggshell calcium in the soil when compared to limestone.

As previously mentioned, studies on calcium carbonate $\left(\mathrm{CaCO}_{3}\right)$ solubilization are scarce, however, considering the importance of calcium for agricultural production, they are extremely necessary to understand the behavior of eggshell in the soil and other alternative sources to limestone.

Seven of the strains used in this study proven efficiency in solubilizing potassium from the phonolite rock (Florentino et al., 2017). The bio solubilization of minerals containing phosphorus and potassium from rock dust has been intensively studied, with promising results being verified (Meena et al., 2014; Restrepo-Franco et al., 2015; Florentino et al., 2017). According to these authors, the strain's potential to solubilize is related to the production of organic acids, with a reduction of the $\mathrm{pH}$ of the culture medium.

In the experiment using soil, it was found that the eggshell and bacterial strains significantly influenced the $\mathrm{K}^{+}, \mathrm{Ca}^{2+}$, and $\mathrm{Mg}^{2+}$ levels (Table 6). Nevertheless, the $\mathrm{pH}$ and potential acidity $(\mathrm{H}+\mathrm{Al})$ of the soil were not significantly modified ( $\mathrm{p}$ $<0.05)$ by the treatments, and the mean values obtained were 4.4 and $48 \mathrm{mmolc}^{-3}$, respectively.

Table 6. Values of calcium $\left(\mathrm{Ca}^{2+}\right)$ and magnesium $\left(\mathrm{Mg}^{2+}\right)$ in soil supplemented or not with eggshell, associated with inoculation with different bacterial strains and incubated for 90 days.

\begin{tabular}{lcc}
\hline Treataments & $\mathrm{Ca}^{2+}\left(\mathrm{mmol}_{\mathrm{c}} \mathrm{dm}^{-3}\right)$ & $\mathrm{Mg}^{2+}\left(\mathrm{mmol}_{\mathrm{c}} \mathrm{dm}^{-3}\right)$ \\
\hline Control & $7,81 \mathrm{e}$ & $5,66 \mathrm{c}$ \\
$100-93$ & $31,09 \mathrm{c}$ & $6,65 \mathrm{c}$ \\
$100-21$ & $33,59 \mathrm{c}$ & $6,34 \mathrm{c}$ \\
$100-167$ & $39,21 \mathrm{~b}$ & $6,34 \mathrm{c}$ \\
$100-16$ & $39,63 \mathrm{~b}$ & $7,26 \mathrm{a}$ \\
$100-13$ & $40,67 \mathrm{~b}$ & $6,87 \mathrm{~b}$ \\
$100-198$ & $43,52 \mathrm{~b}$ & $6,89 \mathrm{~b}$ \\
$100-68$ & $43,89 \mathrm{~b}$ & $7,26 \mathrm{a}$ \\
$100-63$ & $44,12 \mathrm{~b}$ & $7,95 \mathrm{a}$ \\
$100-79$ & $47,12 \mathrm{~b}$ & $6,69 \mathrm{~b}$ \\
$100-39$ & $47,38 \mathrm{~b}$ & $6,82 \mathrm{~b}$ \\
$100-55$ & $59,81 \mathrm{a}$ & $6,87 \mathrm{~b}$ \\
$100-40$ & $67,22 \mathrm{a}$ & $7,06 \mathrm{a}$ \\
\hline Means & 38,05 & 6,84 \\
\hline
\end{tabular}

Means followed by the different letters in column, differ by Scott Knott's test at 5\% probability. Source: Authors (2022). 
Generally, it can be seen that the levels of $\mathrm{Ca}^{2+}$ and $\mathrm{Mg}^{2+}$ increased with the application of eggshell in different treatments when compared with the initial values of the chemical characterization of the soil (Table 3) and with the control treatment (Table 6).

Analyzing the data from tables 4 and 5, different behaviors are observed in the solubilization of $\mathrm{Ca}^{2+}$ from the eggshell in the culture medium and in the soil, as can be observed for the strain 100-55 that did not stand out in the in vitro experiment, in which eggshell was added to the culture medium, but when inoculated into the soil, it promoted greater release of $\mathrm{Ca}^{2+}$, together with strain 100-40, which showed potential to solubilize $\mathrm{Ca}^{2+}$ in both conditions tested, in vitro and in soil.

These results can be explained by the fact that the soil is considered a complex, heterogeneous and dynamic environment (Silveira et al. 2016), and the different types of soils offer favorable conditions for certain bacterial species, thus being able to justify the greater calcium value in the soil inoculated with strains 100-40 and 100-55. Regarding the concentration of $\mathrm{Mg}^{2+}$, the treatments that stood out were those inoculated with strains 100-16, 100-40, 100-63, and 100-68.

No studies were found in the literature reporting on the potential of microorganisms to solubilize $\mathrm{Ca}^{2+}$ and $\mathrm{Mg}^{2+}$ from eggshells, demonstrating the importance of this study, which can serve as a basis for the development of new research, thus enhancing the reuse of eggshells in agriculture.

\section{Conclusions}

Bacterial strains are able to solubilize $\mathrm{Ca}^{2+}$ from eggshells, enabling the use of this residue in agriculture.

\section{Acknowledgments}

The authors thank the CAPES and FAPEMIG agencies for financial support.

\section{References}

Abioye, O. P., Agamuthu, P. \& Adbul Aziz, A. R. (2012). Biodegradation of used motor oil using organic waste amendment. Biotechnology Research International, 44 (1), 93-100.

Ciceri, D., Manning, D. A. C. \& Allanore, A. (2015). Historical and technical developments of potassium resources. Science of the Total Environment, 502 (1), $590-601$.

Dias, M. S., Florentino, L. A., Rabêlo, F. H. S., Rezende, A. V., Souza, F. R. C. \& Borgo, L. (2019). Características morfológicas, produtivas e bromatológicas do capim-xaraés: adubação nitrogenada em cobertura versus inoculação com bactérias diazotróficas. Ciência Animal Brasileira, 20 (1), 1-12.

Fernandes, F. R. C., Luz, A. B. \& Castilos, Z. C. (2010). Agrominerais para o Brasil. Rio de Janeiro: Centro de Tecnologia Mineral. 380 p.

Ferreira, D. F. (2014). Sisvar: um guia dos seus procedimentos de comparações múltiplas Bootstrap. Ciência e Agrotecnologia, 38 (2), 109-112.

Florentino, L. A., Rezende, A. V., Miranda, C. C. B., Mesquita, A. C., Mantovani, J. R. \& Bianchini, H. C. (2017). Potassium solubilization in phonolite rock by diazotrophic bacteria. Comunicata Scientiae, 8 (1), 17-23.

King'ori, A. M. (2011). A review of the uses of poultry eggshells and shell membranes. International Journal of Poultry Science, 10 (11), $908-912$.

Lira-Cadete, L., Farias, A. R. B., Ramos, A. P. S., Costa, D. P., Freire, F. J. \& Sobral, J. K. (2012). Variabilidade genética de bactérias diazotróficas associadas a plantas de cana-de-açúcar capazes de solubilizar fosfato inorgânico. Bioscience Journal, 28 (1), 122-129.

Madigan, M. T., Martinko, J. M., Bender, K. S., Buckley, D. H., Stahl, D. A. \& Bonseca, F. G. (2016). Microbiologia de Brock-14a Edição. Artmed Editora. $1032 \mathrm{p}$.

Magalhães, F. M. M. \& Döbereiner, J. (1984). Occurrence of Azospirillum amazonense in some Amazonian (Brazil) ecosystems. Revista de Microbiologia, 15 (4), 246-252.

Malavolta, E., Vitti, G. C. \& Oliveira, S. A. (1997). Avaliação do estado nutricional das plantas: princípios e aplicações. 2. ed., Piracicaba: Potafos. 319 p.

Medeiros, F. M. \& Alves, M. G. M. (2014). Qualidade de ovos comerciais. Revista Eletrônica Nutritime, 11 (4), $3515-3524$.

Meena, V. S., Maurya, B. R. \& Verma, J. P. (2014). Does a rhizospheric microorganism enhance $\mathrm{K}^{+}$availability in agricultural soils? Microbiological Research, 169 (5), 337-347. 
Research, Society and Development, v. 11, n. 3, e20811326301, 2022

(CC BY 4.0) | ISSN 2525-3409 | DOI: http://dx.doi.org/10.33448/rsd-v11i3.26301

Milbradt, B. G., Muller, A. L. H., Silva, J. S., Lunardi, J. R., Milani, L. G., Flores, E. M. M. \& Callegaro, M. G. K. (2015). Casca de ovo como fonte de cálcio para humanos: composição mineral e análise microbiológica. Ciência Rural, 45 (3), 560-566.

Naemchanthara, K., Meejoo, S., Onreabroy, W. \& Limsuwan, P. (2008). Temperature Effect on Chicken Egg Shell Investigated by XRD, TGA and FTIR. Advanced Materials Research, 55 (1), 333-336.

Oliveira, H. B., Rocha, E., Teles, T., Florentino, L. A. (2022). Microbial Activity in the Agricultural and Forestry System. Research, Society and Development, $11(2)$, e56211226184.

Pádua, S. D. \& Florentino, L. A. (2022). Use of phonolite and potassium-solubilizing bacteria in bean crops. Research, Society and Development, 11 (2), p. e53711226248.

Park, H. J., Grabinska, K. A., Guan, Z., Stránecky, V., Hartmannova, H., Hodanová, K., Baresová, V., Sovová, J., Jorsef, L., Ondrusková, N., Hansíková, H., Honzík, T., Zeman, J., Hulková, H., Wen, R., Kmoch, S. \& Sessa, W. (2014). Mutation of Nogo-B receptor, a subunit of cis-prenyltransferase, causes a congenital disorder of glycosylation. Journal of Environmental Sciences, 20 (3), 448-445.

Popovi, T., Balaz, J., Nikolic, Z. T., Starovic, M., Gavrilovic, V. M., Goran, A., Vasic, M. A. \& Zivkovic, S. (2010). Detection and identification of Xanthomonas axonopodis pv. phaseoli on bean seed collected in Serbia. African Journal of Agricultural Research, 5 (19), $2730-2736$.

Restrepo-Franco, G. M., Marulanda-Moreno, S., Fe-Perez, Y., Diaz-de La Osa, A., Baldani, V. L. D. \& Hernandez-Rodriguez, A. (2015). Bacterias solubilizadoras de fosfato y sus potencialidades de uso en la promoción del crecimiento de cultivos de importancia económica. Revista Cenic, 46 (1), $63-76$.

Rodrigues, A. S. \& Ávila, S. G. (2017). Caracterização físico-química da casca de ovo de galinha e utilização como fonte para produção compostos de cálcio. Revista Virtual de Química, 9 (2), 596-607.

Santos, S. T. S., Gois, M. A. C., Simões, A. O. \& Garcia, C. A. B. (2012). Análises dos constituintes inorgânicos da casca do ovo. Scientia Plena, 8 (3), 1-4.

Silva, F. C. (2019). Avaliação dos contratos do plano de agricultura de baixo carbono, para recuperação de pastagens degradadas, por ferramentas de MRV (Monitoramento, Relato e Verificação). Dissertação. Escola de Economia de São Paulo, Fundação Getúlio Vargas, São Paulo. 88 p.

Silveira, N. H., Rabêlo, F. H. S., Rezende, A. V., Rabelo, C. H. S. \& Bianchini, H. C. (2016). Casca de ovo como fonte de cálcio na produção, nutrição e composição bromatológica dos capins Piatã e Marandu. Revista de Engenharia Agrícola e Ambiental, 20 (2), 113-118.

Tedesco, M. J. (1995). Análises de solo, plantas e outros materiais. Porto Alegre: Universidade Federal do Rio Grande do Sul (UFRGS), 2 a. edição. 174 p.

Terra, A. B. C., Souza, F. R. C., Mantovani, J. R., Rezende, A. V. \& Florentino, L. A. (2019). Physiological characterization of diazotrophic bacteria isolated from Brachiaria brizantha rhizosphere. Revista Caatinga, 32 (3), 658-666.

Thapon, J. L. \& Bourgeois, C. M. (1994). Lavousier Technique at Documentation. L'Oeuf et les ovoproducts. 334 p.

Vital, A. F. M., Barbosa, I. S. \& Mede, A. (2018). Compostagem de resíduos sólidos orgânicos e produção de biofertilizante enriquecido. Revista Saúde e Ciência, 7 (2), 539-551.

Xiang, L., Kong, W., Su, J., Liang, J., Zhang, G., Xie, L. \& Zhang, R. (2014). Amorphous calcium carbonate precipitation by cellular biomineralization in mantle cell cultures of Pinctada fucata. PLoS One, 18 (11), 113-150. 